\title{
Morpho and Cytological Differentiation of Calli of Eucalyptus grandis x Eucalyptus urophylla During Somatic Embryogenesis
}

\author{
Tânia Regna Batista ${ }^{1}$, Evânia Galvão Mendonça ${ }^{2}$, Marlúcia Souza Pádua ${ }^{3 *}$, Vanessa \\ Cristina Stein ${ }^{4}$, Luciano Paiva ${ }^{5}$ \\ ${ }^{1}$ Universidade de São Paulo - Campus de Piracicaba, Piracicaba, São Paulo, Brazil ; ${ }^{2}$ Universidade Federal Rural \\ do Rio de Janeiro, Seropedica, Rio de Janeiro, Brazil ${ }^{3}$ Universidade Federal de Lavras - Biotecnologia Campus \\ Universitário - Laboratório Central de Biologia Molecular, Lavras, Minas Gerais Brazil ${ }^{4}$ Universidade Federal de \\ São João Del Rei - Campus Dona Lindu, Divinopólis, Minas Gerais, Brazil ${ }^{5}$ Universidade Federal de Lavras - \\ Chemistry - LCBM , Lavras, Minas Gerais, Brazil
}

\begin{abstract}
The aim of this study was to induce and analyze embryogenic calli from two types of explants (leaves and meristems) of the hybrid Eucalyptus grandis $x$ Eucalyptus urophylla. Leaves and meristems of plants kept in a nursery were disinfected and inoculated in Petri dishes containing MS culture medium supplemented with different concentrations of the growth regulator dicamba $(1.13,4.52$, and $9.04 \mu M)$ and without it. At 60 days of culturing, the calli were analyzed by scanning electron microscopy and at 90 days were evaluated by light microscopy in regard to the embryogenic characteristics of the cells. Different type of calli were induced in leaf explants, designated as Type I with light yellow coloring, Type II with dark yellow coloring, and Type III of brown coloring; however, only Type I had embryogenic characteristics. In the meristematic explants, only one type of callus was induced, and it had embryogenic characteristics. At 90 days of culturing, the formation of somatic embryos in the different embryogenic stages was observed and the formation of procambium, protoderm, and ground meristem tissues. At 150 days of culturing, the concentration of $1.13 \mu \mathrm{M}$ of dicamba was prominent in the formation of somatic embryos in the different embryogenic stages.
\end{abstract}

Keywords: Anatomical analyses, Dicamba, Eucalyptus, Somatic embryos, Ultrastructural analyses.

\footnotetext{
* Author for correspondence: marluciabio@yahoo.com.br
} 


\section{INTRODUCTION}

The Eucalyptus genus has great economic importance due to the use of some commercial hybrids from which wood and fiber are taken and directed to the cellulose and paper industry; it is also used for veneer, firewood, as an ornamental plant, and for production of essential oil. The main characteristics of this plant are rapid growth, large biomass production, good quality wood, high pulp yield, and the ability to grown in diverse environments and soils ${ }^{32,23}$.

Nevertheless, propagation of the Eucalyptus genus mainly occurs through seeds, which can generate high heterozygosity, a fact that impedes large scale clonal propagation. In this context, with a view toward wide use of Eucalyptus and the need to expand its cultivation, biotechnological alternatives, such as clonal propagation, can assist in conservation of the characteristics of economic importance of commercial hybrids, as well as maintain uniformity, favoring harvest operations ${ }^{12}$.

Among the technologies directed to clone production, tissue culture stands out, with in vitro production of plants by means of organogenesis and somatic embryogenesis. Organogenesis in Eucalyptus is widely reported in the literature as successful ${ }^{1,6,18}$, while studies on somatic embryogenesis are few.

Somatic embryogenesis has drawn special interest from research institutions and Brazilian forestry companies, which have advanced plant breeding and cloning programs $^{30}$ since the technique allows propagation on a larger scale than organogenesis and, moreover, minimizes the occurrence of chimeras generated by the organogenic route ${ }^{33,8}$.

Somatic embryogenesis is the process by which somatic cells change their path of development, becoming totipotent, and one cell alone is able to originate a complete plant with the formation of somatic embryos ${ }^{9}$, by either a direct or indirct route. Direct somatic embryogenesis consists of formation of somatic embryos directly from the explants, without the formation of the intermediate stage of the callus, and the indirect occurs through callus formation. This is more advantageous than the direct route by the fact of obtaining a larger number of plants ${ }^{20}$.

Within the Eucalyptus genus, somatic embryogenesis has already been studied in the species Eucalyptus urophylla S.T.Blake ${ }^{3}$ Eucalyptus globulus Labill, and E. saligna Sm. $\times$ E. maidenii F. Muell ${ }^{8}$, Eucalyptus globulus Labill ${ }^{17,23,22,24}$, Eucalyptus camaldulensis Dehnh ${ }^{25}$, and Eucalyptus grandis W.Hill ${ }^{30}$. Nevertheless, somatic embryogenesis for Eucalyptus still faces some difficulties, such as the low frequency of callus and somatic embryo induction and lack of efficiency in conversion and regeneration of plants ${ }^{23,25}$.

In this context, it is necessary to optimize the somatic embryogenesis process in eucalyptus, and anatomical studies during somatic embryogenesis can assist in verification of the embryogenic potential of the calli ${ }^{19}$. Cells can be studied by means of cytochemical analyses, which allow embryogenic characteristics to be observed, such as small cells arranged in clusters, with a large nucleus and prominent nucleolus.

Histochemical analyses allow analysis of embryo development, such as tissue formation - the procambium, ground meristem, and protoderm - and possible abnormalities in the somatic embryos ${ }^{10,12}$. In addition, through microscopic analyses, they can differentiate the structures formed, the regeneration process, and characterize the globular, heart-shaped, torpedo, and cotyledonary embryogenic stages. In the in vitro regeneration process, the presence or the absence of synchrony of the somatic embryos can be observed and identification of flaws in formation of the somatic embryo, so as to prevent the production of abnormal plants ${ }^{11,13}$. 
The aim of this study was to compare two types of explants (meristems and leaves) to induce embryogenic calli and somatic embryos, and evaluate the somatic embryogenesis process by means of microscopic analyses using a commercial hybrid of E. grandis x Eucalyptus urophylla.

\section{MATERIALS AND METHODS}

\section{Plant Matter and Disinfestation}

The experiments were conducted in the Central Laboratory of Molecular Biology and in the Electronic Microscopy Laboratory, both located on the campus of the Universidade Federal de Lavras.

The plant matter used in this study was leaf explants and stem apex excised from plants of the hybrid E. urophylla S. T. Blake $\mathrm{x}$ E. grandis W. Hill grown in a commercial nursery in Lavras, MG, Brazil.

For disinfection, leaf explants and stem apices of the sprouts were collected, placed in a laminar flow chamber, and disinfected in Petri dishes closed with paraformaldehyde tablets for 40 minutes. After disinfection, the meristems were excised using a Zeiss Stemi 2000 stereomicroscope.

\section{Induction of Embryogenic Calli}

Leaf explants of $1 \mathrm{~cm}$ length and the meristems were inoculated in Petri dishes containing $30 \mathrm{~mL}$ of MS culture medium ${ }^{14}$ with the addition of dicamba auxin at different concentrations $(1.13,4.52$, and $9.04 \mu \mathrm{M})$ and without it. The culture media were solidified with $0.6 \%$ agar, supplemented with $3 \%$ sucrose and the $\mathrm{pH}$ was adjusted to $5.7 \pm 0.1$ before autoclaving at $121^{\circ} \mathrm{C}$ for 20 minutes.

The experiment was conducted in a growth chamber at a temperature of approximately $25 \pm 0.1^{\circ} \mathrm{C}$ in the absence of light for a period of 150 days.

The calli obtained from the leaves were classified in types according to color. At 60 days after inoculation of the explants, the calli were collected for analysis in a scanning electron microscope (item 3) and at 90 days for evaluation in a light microscope (item 4).

At 150 days of culturing, the number of embryos formed and the embryogenic stage they were in were evaluated.

The statistical design was completely randomized with 4 treatments, 5 replications, and 7 plots. Statistical analysis was made on the Sisvar ${ }^{\circledR}$ software ${ }^{10}$ using the Tukey test at 5\% significance; the data of variable number of somatic embryos were transformed by the equation $\sqrt{ } \mathrm{y}+0.5-\mathrm{SQR}(\mathrm{y}+0.5)$.

\section{Scanning Electron Microscopy}

The callus samples obtained from the meristems and from leaves classified as Type I, II, and III were collected at 60 days of culturing and fixed in Karnovsky solution (2.5\% glutaraldehyde and $2.5 \%$ paraformaldehyde) in cacodylate buffer $0.05 \mathrm{M}, \mathrm{pH}$ 7.0 , for 24 hours at $4^{\circ} \mathrm{C}$. Subsequently, the callus were placed in $30 \%$ glycerol for 30 minutes and then immersed in liquid nitrogen to be cut with a scalpel. The fragments were washed three times (10 minutes) in $0.05 \mathrm{M}$ cacodylate buffer and post-fixed in $1 \%$ osmium tetroxide for two hours. Later, the fragments were dehydrated in an acetone gradient $(25,50,75$ and $90 \%)$ for 10 minutes each and $100 \%$ acetone twice for 10 minutes. The samples were then taken to the critical point apparatus using liquid $\mathrm{CO} 2$ to complete drying. Finally, the samples were mounted on aluminium 
supports (stubs), coated with gold using a gold evaporator SDC 050 and observed in a scanning electron microscope LEO EVO 40XVP 5.

\section{Histological Analyses}

At 90 days after inoculation, the samples of calli induced from leaves and meristems were collected and fixed in FAA50 (formaldehyde, glacial acetic acid, and 50\% ethyl alcohol) for 48 hours, and then conserved in $70 \%$ ethyl alcohol. Soon after, the material was dehydrated in ethanol and embedded in Leica historisin in accordance with manufacturer's protocol, with modifications ${ }^{5}$. A rotary microtome was used to cut $5 \mu \mathrm{m}$ thick sections. The sections were stained with toluidine blue at a concentration of $0.1 \%$ and visualized in a Leica optical microscope at magnifications of $10 \mathrm{X}$ and $20 \mathrm{X}$.

\section{RESULTS AND DISCUSSION}

The two explants evaluated in this study showed different responses in relation to callus induction. The calli obtained from leaf explants exhibited different colors in all the treatments containing dicamba and were classified by three types: Type I with light yellow color, Type II with dark yellow color, and Type III with brown color. The Type I calli, visualized in a scanning electron microscope exhibited embryogenic characteristics with predominance of small cells with isodiametric shape, forming cell clusters (Fig. 1a). The cells of Type II calli exhibited an elongated and shriveled shape, characteristic of unviable cells (Fig. 1b). In the Type III calli, masses of undifferentiated cells were observed with a compact appearance, and also elongated cells, with few rounded cells (Fig. 1c). The calli of the meristematic explants did not exhibit differences in relation to color and were generally beige with a globular appearance; they contained isodiametric cells, characteristic of viable cells, and few regions with large shriveled cells, visualized in a scanning electron microscope (Fig. $1 d)$. 

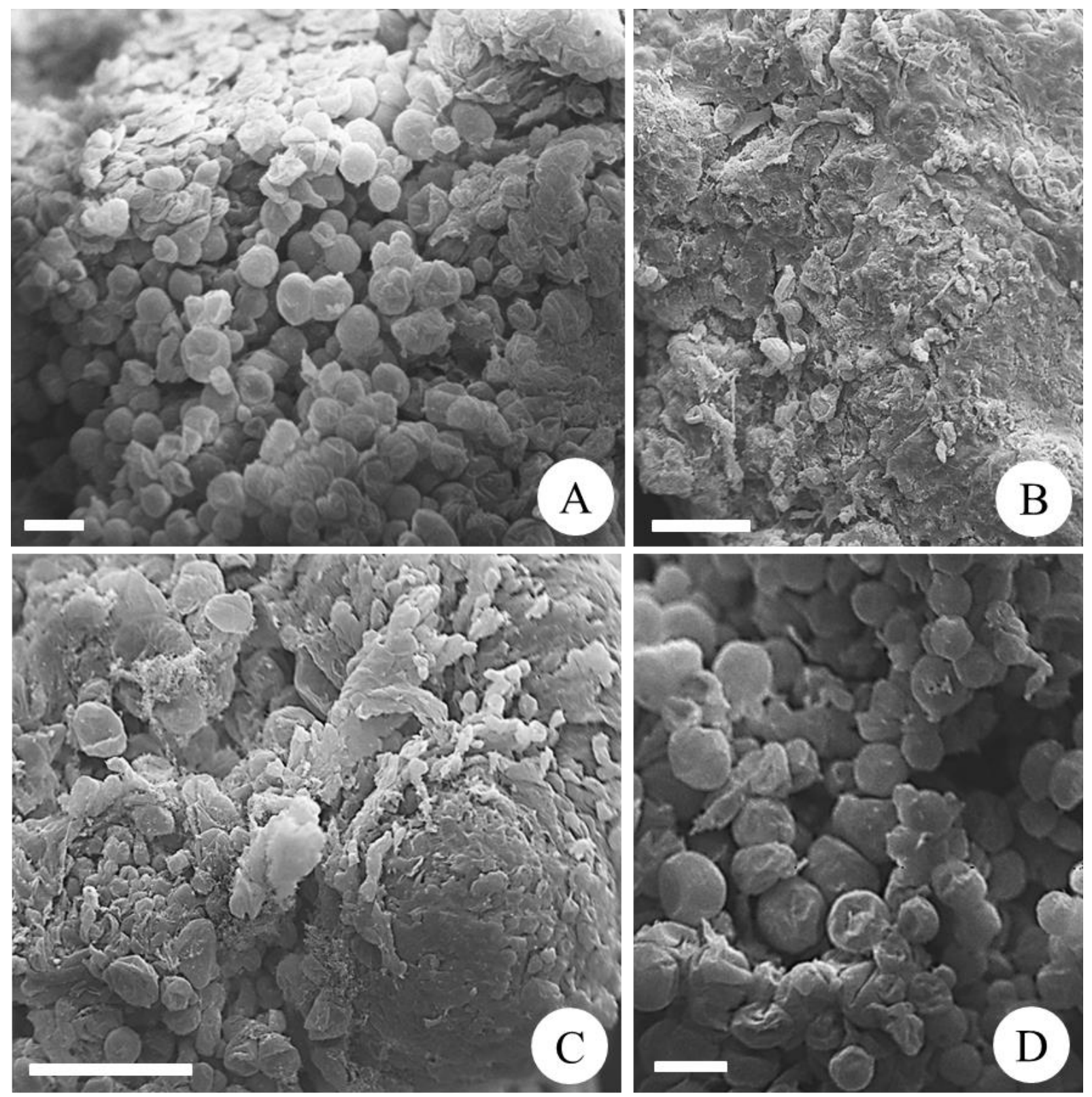

Figure 1. Scanning electron micrographi of callus of the hybrid of E. grandis x E. urophylla induced from leaf explants. A) Type I with pale yellow color presenting cells with isodiametric format forming cellular agglomerates; B) Type II of dark yellow coloration, cells with a waxy appearance and elongated shape; C) Type III with brown color, with compact appearance and D) Clusters in meristematic explants of beige and globular appearance. Bars = $100 \mu \mathrm{m}$.

The formation of three types of calli also identified in the banana plant. These authors observed that the Type I calli with transparent and aqueous appearance had elongated cells, Type II was characterized by small yellow aggregations containing clustered cells with greater embryogenic potential, and Type III with large yellow clusters with isodiametric cells ${ }^{26}$.

In oil palm trees, the presence of diverse types of calli in the same culture medium was also observed, and by means of cytochemical analyses, the authors identified that the beige and globular calli have embryogenic characteristics ${ }^{19}$. Various authors report that beige-colored nodular calli have embryogenic characteristics, such as the calli obtained from leaf explants of oil palm ${ }^{19}$, passion fruit plants ${ }^{7}$, and eucalyptus ${ }^{8}$. In the 
beige and globular calli of oil palm, observed the formation of globular structures and cells with a large nucleus and prominent nucleolus with a large amount of starch, characterizing embryogenic cells ${ }^{19}$.

The meristematic explants at 60 days of culturing, showed the formation of structures such as calli and roots (Fig. 2a) in all the treatments containing the dicamba growth regulator.
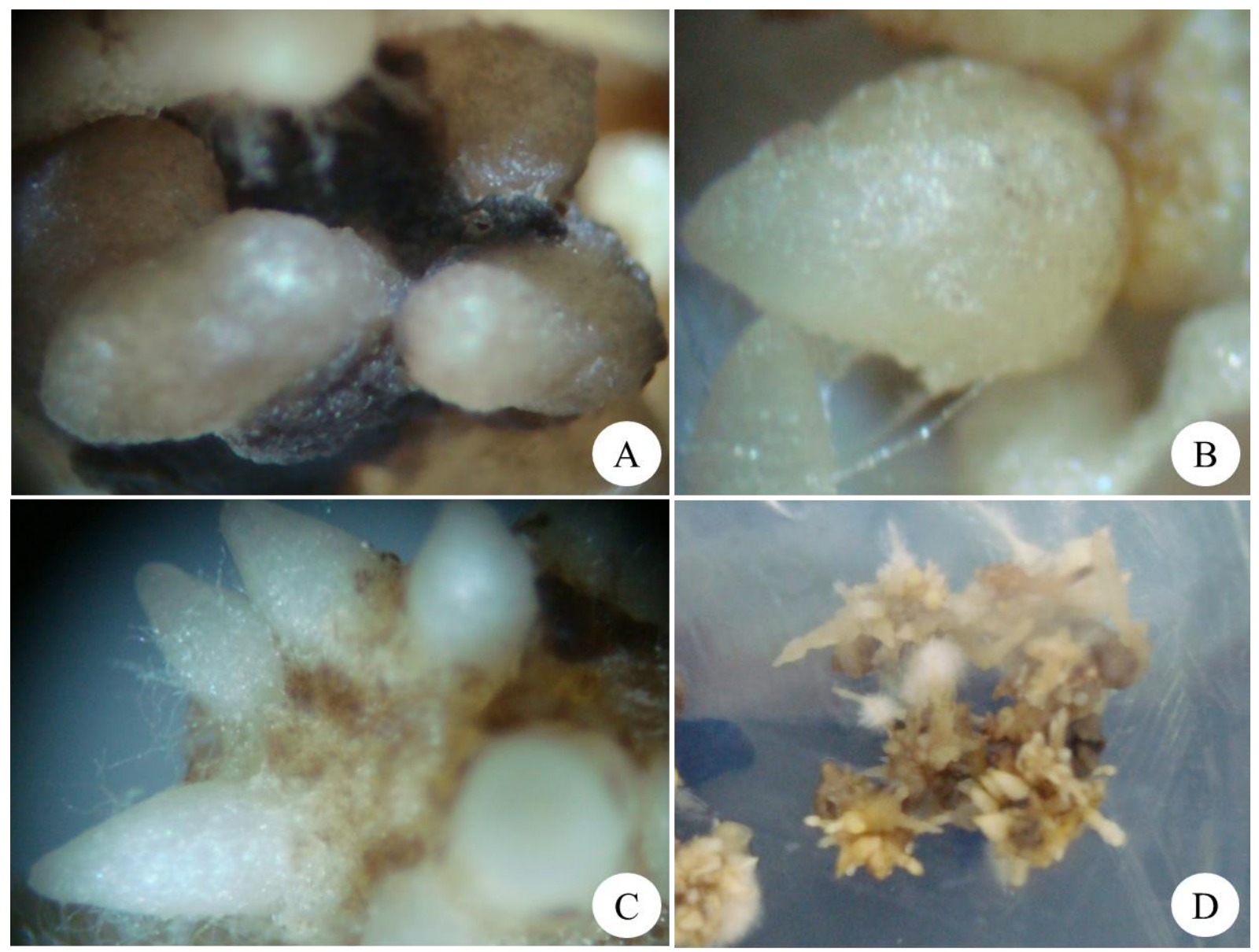

Figure 2. Calcium obtained from meristematic explants of E. grandis x E. urophylla. A) General appearance of calluses with embryos and roots; B) callus with globular embryos and C) torpedoes D) roots.

The presence of roots and calli in the same culture medium was also observed in Eucalyptus grandis in the presence of dicamba growth regulator in all the concentrations evaluated $\left(0.25,5.0,1.0 \text {, and } 2.0 \mathrm{mg} \mathrm{L}^{-1}\right)^{30}$.

Different types of calli of $E$. camaldulensis were observed when the growth regulators ANA and 2,4-D were introduced in the culture medium, using zygotic embryos as explants. At low concentrations of 2,4-D, white-colored friable calli were observed and high concentration of the growth regulator 2,4-D induced the formation of hard calli. In the culture medium containing the auxin ANA, friable and nodular calli were observed, and a greater percentage were visualized when zygotic embryos were used as explants, with $2 \mathrm{mg} \mathrm{L}^{-1}$ of ANA, which later regenerated plants ${ }^{25}$.

Somatic embryogenesis in E. globulus was evaluated using different explants: stem, hypocotyl, leaf, cotyledon, and zygotic embryos. Only cotyledonary explants and zygotic embryos using the growth regulator 2,4-D $\left(1 \mathrm{mg} \mathrm{L}^{-1}\right)$ associated with ANA (1 $\left.\mathrm{mg} \mathrm{L}^{-1}\right)$ or only the growth regulator ANA $\left(3 \mathrm{mg} \mathrm{L}^{-1}\right.$ or $\left.5 \mathrm{mg} \mathrm{L}^{-1}\right)$ were successful ${ }^{23}$. 
Different responses in callus induction of $E$. grandis were observed in the presence of the dicamba growth regulator when the zygotic embryo, hypocotyl, and cotyledons were used as explants. These authors did not observe callus formation in zygotic embryos. In cotyledonary explants, greater induction of calli was observed with 0.5 $\mathrm{mg} \mathrm{L}^{-1}$ of the growth regulator dicamba, and for the hypocotyl, a greater percentage of calli was obtained with $2.0 \mathrm{mg} \mathrm{L}^{-1}$ of dicamba ${ }^{30}$. Embryogenic calli of two genotypes of eucalyptus, Sal-May (E. saligna $\times$ E. maidenii) and 41-1-AC (E. globulus), were obtained from the same explants used in this study, meristems and leaves, in the presence of the growth regulator $\mathrm{ANA}^{8}$.

The meristematic explants have more undifferentiated cells than the leaf explants, which influences the dedifferentiation and totipotency of the explants used. This can explain the absence of the types of calli observed in the leaf explants (Type II and III), which do not have embryogenic cell characteristics. This is characterized as a morphogenic response, the older the explant, the lower the potential for forming embryogenic calli ${ }^{25}$.

Embryogenic calli can differ from the non-embryogenic ones in external morphology, but especially in cellular and intercellular characteristics ${ }^{27}$. In addition, the morphological characteristics related to the color of the embryogenic calli are related to the species under study, which makes it difficult to characterize them.

In this context, cell analyses allow the cells with embryogenic potential to be differentiated from the non-embryogenic ones. Large dispersed cells, that is, those that do not form clusters, are signs of unviable cells. The percentage and the type of calli induced depend on the explant used, the auxin, and the concentration used ${ }^{25}$.

At 90 days of culturing, the calli obtained from leaf explants were evaluated in a light microscope. The Type I calli had small isodiametric cells with a large nucleus, arranged in clusters called meristematic centers. The Type II calli had large cells that were elongated and dispersed similar to Type III cells (Fig. 3).
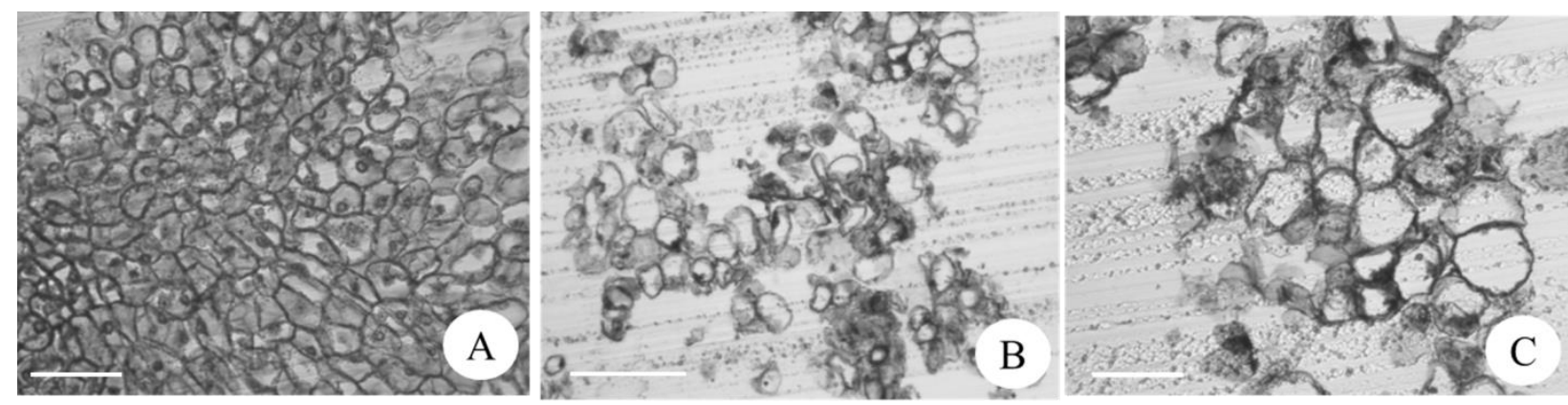

Figure 3. Photomicrographs of callus types of E. grandis X E. urophylla obtained from leaf explants. A) Type I callus cells presenting large nuclei (arrows), isodiametric format and arranged in clusters, stained with toluidine blue. B) Type II callus cells with elongated and dispersed large cells (arrows), stained with toluidine blue; C) Type III callus showing large cells (arrows) and no nucleus apparent stained with toluidine blue. Bars $=100 \mu \mathrm{m}$.

In calli of E. urophylla, similar characteristics were observed, such as isodiametric cells with a prominent nucleus and high mitotic activity, denominated meristematic centers, which later developed into somatic embryos ${ }^{3}$.

The calli induced from meristems at 90 days of culturing had somatic embryos in different embryogenic stages: globular, heart-shaped, and torpedo, manifesting their asynchrony (Figs. 4A, 4B, and 4C). 

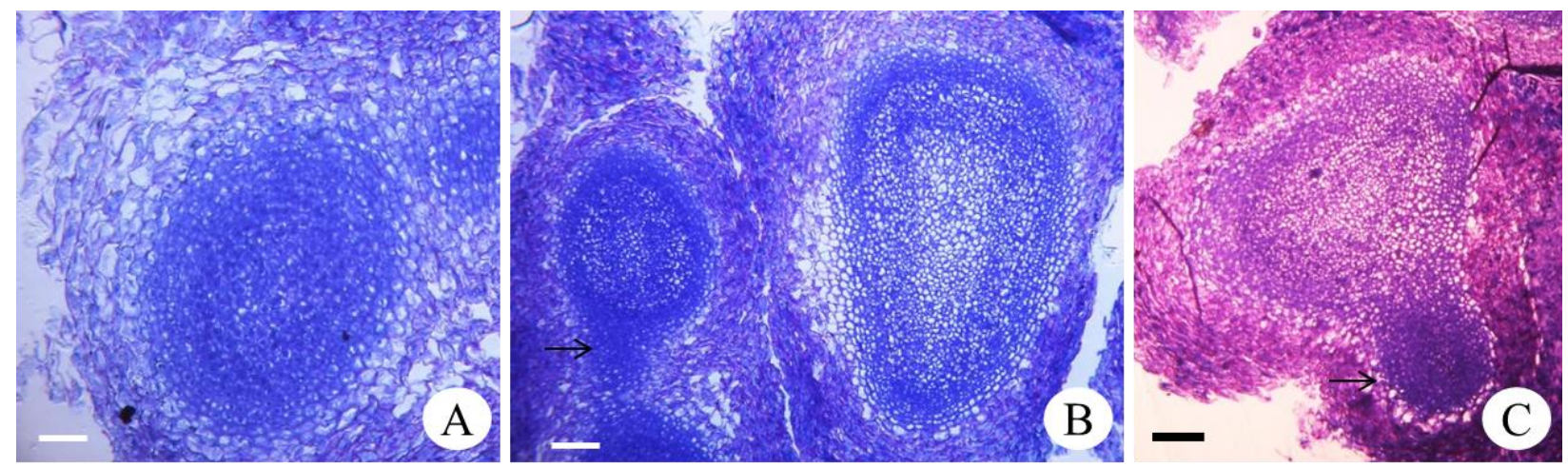

Figure 4. Photomicrographs of callus of E. grandis X E. urophylla obtained from meristematic explants. A) Mass formation of globular cells in callus with small isodiametric cells stained strongly by toluidine blue. B) Embryo in stage and suspender (arrow) and embryo at the beginning of the cordiform stage. C) Somatic embryo torpedo and suspensor (arrow). Bars $=50 \mu \mathrm{m}$.

The presence of pro-embryos, developing in the cell mass with embryogenic characteristics, was also observed in macauba ${ }^{14}$ and in oil $\mathrm{palm}^{2}$. They developed, separating from the mass of cells, into somatic embryos in the globular stage, passing through the embryogenic stages, and later germinated into plants.

The absence of synchrony of the somatic embryos of eucalyptus was observed in developed calli of mature zygotic embryos of E. globulus, for which better synchrony was observed when the somatic embryos were transferred to the culture medium without growth regulators, indicating that the presence of growth regulators in the culture medium can induce continuity of formation of new somatic embryos ${ }^{22}$. These authors observed greater asynchrony predominating in the somatic embryos in the globular and cotyledonary stages in E. globulus.

Another condition that can lead to asynchrony of the somatic embryos is related to culturing in solid medium, due to lower renewal of nutrients compared to the liquid medium, which provides greater contact with nutrients ${ }^{28}$.

In the process of somatic embryogenesis of oil palm, asynchronous formation of somatic embryos was also observed ${ }^{4}$ and was likewise observed in culturing of somatic embryos of cassava, using a culture medium supplemented with the growth regulator $\mathrm{BAP}^{31}$.

In this study, somatic embryos were observed at 90 days of culturing in embryogenic calli obtained from meristematic explants. In calli of Eucalyptos grandis, in which explants of hypocotyl and cotyledons were used, inoculated in culture medium supplemented with $2.26 \mu \mathrm{M}$ of dicamba, the formation of somatic embryos was observed at 30 days of culturing ${ }^{30}$.

At 150 days of culturing, the calli obtained from meristematic explants in all the treatments containing the dicamba auxin, regenerated into somatic embryos. In the treatments containing $1.13 \mu \mathrm{M}$ and $4.52 \mu \mathrm{M}$ of dicamba, somatic embryos were observed in all the embryogenic stages, and the treatment with $1.13 \mu \mathrm{M}$ had the largest number of embryos, with a mean of 19 embryos/callus (Fig. 5). 


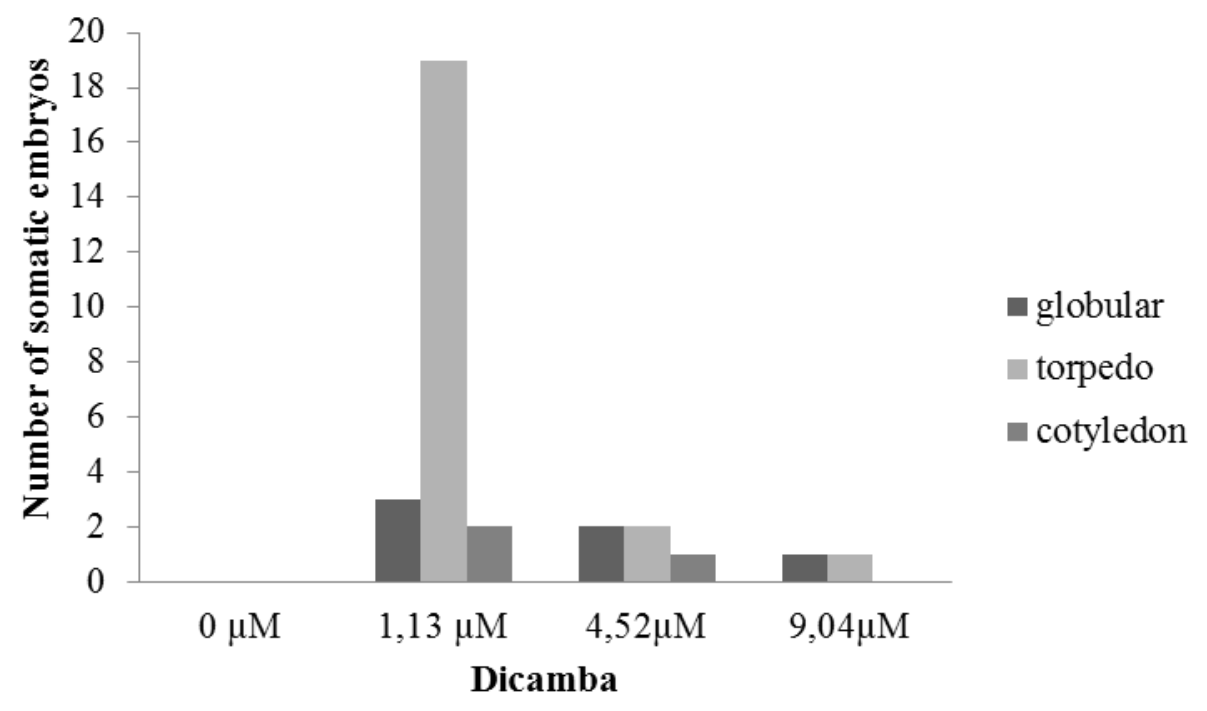

Figure 5. Number of somatic embryos obtained from meristematic explants of E. grandis x E. urophylla, by treatment and number of somatic embryos of each embryogenic stage.

The dicamba growth regulator has been described as an effective auxin to obtain calli in a short period of time and to obtain a higher number of somatic embryos ${ }^{29}$. Studying somatic embryogenesis in E. grandis, observed the formation of somatic embryos in the heart and torpedo shape using the dicamba auxin $\left(2.0 \mathrm{mg} \mathrm{L}^{-1}\right)^{30}$.

In eucalyptus, in studies with the species Sal-May (E. saligna $\times$ E. maidenii), the formation of 2 to 10 somatic embryos per explant was observed in a culture medium supplemented with $40 \mu \mathrm{M}$ of Picloram ${ }^{7}$. A higher mean number of 45 somatic embryos per explant was obtained from leaf explants of Coffea arabica L. cv. Acaiá in culture medium supplemented with kinetin at a concentration of $29.95 \mu \mathrm{M}$ associated with $28.87 \mu \mathrm{M}$ of $\mathrm{GA}_{3}{ }^{21}$.

Somatic embryos obtained from explants of hypocotyls and cotyledons of E. globulus in a medium supplemented with the auxins picloram and AIB; however, they did not observe the formation of somatic embryos when grown in a culture medium supplemented with the auxin dicamba at concentrations of 10 and $20 \mu \mathrm{M}$, suggesting that the type of explant had a direct influence on the response ${ }^{17}$.

\section{CONCLUSION}

The growth regulator dicamba promoted the formation of calli with embryogenic characteristics at all the concentrations evaluated and in both the explants, meristem and leaves, with calli of light yellow color (Type I).

The MS culture medium supplemented with $1.13 \mu \mathrm{M}$ of dicamba was more efficient in the formation of somatic embryos in the different embryogenic stages in the calli obtained from meristematic explants.

The embryogenic characteristics in the callus cells and the embryogenic stages of the somatic embryos could be observed by cyto- and histochemical tests and by means of scanning electron microscopy. 


\section{AKNOWLEDGMENTS}

To the Conselho Nacional de Desenvolvimento Científico e Tecnológico (CNPq), the Fundação de Amparo à Pesquisa de Minas Gerais (FAPEMIG) and the Coordenação de Aperfeiçoamento de Pessoal de Nível Superior (CAPES).

\section{REFERENCES}

1. Alves ECSC, Xavier A, Otoni WC. Organogênese de explante foliar de clones de Eucalyptus grandis x E. urophylla. Pesq. Agropec. Bras.2004;39 (5): 421-430.

2. Ângelo C da S, Steinmacher DA, Lopes R, Cunha RNV da, Guerra MP. Histological analysis and transcription profiles somatic embryogenesis in interspecific hybrids of Elaeis guineenses x Elaeis oleifera. Agr. Sci. 2013; 4(11A):1-11.

3. Arruda SCC, Souza GM, Almeida M, Gonçalves AN. Anatomical and biochemical characterization of the calcium effect on Eucalyptus urophylla callus morphogenesis in vitro. Plant Cell Tiss. Org. Cul. 2000; 63(2):143-154.

4. Bar OAE, Dawayat MME. 2014. Histological changes on regeneration in vitro culture of date palm (Phoenix dactylifera) leaf explants. Aust. J. Crop. Sci. 2014; 8(6):848-855.

5. Bossola JJ and Russell LD. Electron Microscopy. 2nd ed., Boston: Jones and Bartlett Publishers; 1999. $670 \mathrm{p}$.

6. Brondani GE, Araujo MA, Alcântara BK de, Carvalho JG, Gonçalves NA, Almeida M de. 2012. In vitro organogenesis of Eucalyptus grandis: effects of boron and calcium. Acta Scientiarum 34:403-411.

7. Carvalho MA de F, Paiva R, Alves E, Nogueira, RC, Stein VC, Castro EM de et al.Morphogenetic potential of native passion fruit (Passiflora gibertii N. E. Brown.) calli. Braz. J. Botany. 2013; 36(2):473-497.

8. Corredoira E, Ballester M, Ibarra M, Vieitez AM. Induction of somatic embryogenesis in explants of shoot cultures established from adult Eucalyptus globulus and E. saligna X E. maidenii trees. Tree Physiol. 2015; 35(6):678-690.

9. Elhiti M, Stasolla C. Ectopic expression of the Brassica shoot meristemless attenuates the deleterious effects of the auxin transport inhibitor TIBA on somatic embryo number and morphology. Plant Sci. 2011; 180(2):383-390

10. Ferreira DF. SISVAR: um programa para análise e ensino de estatística. Revista Ciência e Agrotecnologia. 2011; 3(6):1039-1042.

11. Filippi SB, Appezzato-Da-Gloria B, Rodriguez APM. Variações morfológicas de embriões somáticos obtidos a partir de inflorescências de bananeira. Sci. Agric. 2001; 58(4):711-716

12. Golle DP, Reiniger LRS, Curti AR, Bevilacqual. Melhoramento florestal: ênfase na aplicação da biotecnologia. Ciênc. Rural. 2009; 39(5):1606-1613.

13. Moura EF, Motoike SY. Induction of somatic embryogenesis in immature seeds of guava tree cv. Paluma. Rev. Bras. Frutic. 2009; 31(2):507-511.

14. Moura EF, Ventrella MC, Motoike SY, Sá Júnior AQ de, Carvalho M, Manfio C E. Histological study of somatic embryogenesis induction on zygotic embryos of macaw palm (Acrocomia aculeata (Jacq.) Lodd. Ex Martius). Plant Cell Tiss Org. 2008; 95(2):175-184.

15. Murashigue T, Skoog F. A Revised Medium for Rapid Growth and Bio Assays with Tobacco Tissue Cultures. Physiol. Plant. 1962; 15:473-497.

16. Nogueira RC, Paiva R, Porto JMP, Nicioli PM, Stein VC, Deuner S, et al. Análise Ultraestrutural de Calos Embriogênicos de murici-pequeno (Byrsonima intermedia A. Juss.). Rev Bras Bioc. 2007; 5(2):48-50.

17. Nugent G, Chandler SF, Whiteman P, Stevenson TW. Somatic embryogenesis in Eucalyptus globulus. Plant Cell Tiss Org. 2001; 67(1):85-88.

18. Oliveira-Cauduro Y de, Adamuchio LG, Degenhardt-Goldbach J, Bespalhok Filho JC, Diba $\mathrm{R}$, Quoirin M. Indirect organogenesis from leaf explants and in vitro shoots multiplication of Eucalyptus benthamii X Eucalyptus dunnii. Ciência Florestal 24:347-355.

19. Pádua MS, Paiva LV, Labory CRG, Alves E, Stein CS. Induction and characterization of oil palm (Elaeis guineensis Jacq.) pro-embryogenic masses. An Acad Bras Ciênc. 2013; 85(4): 1545-1556. 
20. Paul S, Dam A, Bhattacharyya A, Bandyopadhyay TK. An efficient regeneration system via direct and indirect somatic embryogenesis for the medicinal tree Murraya koenigii. Plant Cell Tiss Org. 2011; 105(2):271-283.

21. Pereira AB, Carvalho SP de, Pasqual M, Santos FC. Embriogênese somática direta em explantes foliares de Coffea arabica L. Cv. Acaiá cerrado: efeito de cinetina e ácido giberélico. Ciênc. Agrotec. 2007; 31(2):332-336

22. Pinto G, Park Y-S, Neves L, Araujo C, Santos C. Genetic control of somatic embryogenesis in Eucalyptus globulus Labill. Plant Cell Rep. 2008; 27(6):1093-1101.

23. Pinto G, Santos C, Neves L, Araujo C. Somatic embryogenesis and plant regeneration in Eucalyptus globulus Labill. Plant Cell Rep. 2002; 21(3):208-213.

24. Pinto G, Silva S, Loureiro J, Costa A, Dias MC, Araújo C. et al. Acclimatization of secondary somatic embryos derived plants of Eucalyptus globulus Labill.: an ultrastructural approach. Trees. 2011; 25(3):383-392

25. Prakash MG, Gurumurthi K. Effects of type of explant and age, plant growth regulators and medium strength on somatic embryogenesis and plant regeneration in Eucalyptus camaldulensis. Plant Cell Tiss Org. 2010; 100: 13-20.

26. Ribeiro L de O, Paiva LV, Pádua MS, Santos, BR, Alves E, Stein VC. Morphological and ultrastructural analysis of various types of banana callus, cv. Prata anã. Acta Sci Agr. 2012; 34(4):423-429.

27. Shang H, Liu C, Zhang C, Li F, Hong H, Li F. Histological and ultrastructural observation reveals significant Cellular Differences between Agrobacterium Transformed Embryogenic and Non-embryogenic Calli of Cotton. J Integr Plant Biol. 2009; 51(5): 456-465.

28. Sumaryono RI, Kasi PD, Ginting G. Growth and differentiation of embryogenic callus and somatic embryos of oil palm (Elaeis guineensis Jacq.) In Temporary Immersion System. Indones. J. Agric. Sci.2008; 1(2):109-114.

29. Te-Chato S, Hilae A, Yeedum I. Histological study on oil palm of somatic embryos development as affected by sources of leaf explants and auxin. J Agr Sci. 2003; 36(3): 243250.

30. Titon M, Xavier A. Otoni WC, Motoike SY. Efeito dos reguladores de crescimento dicamba e picloram na embriogênese somática em Eucaliptus grandis. Rev. Árvore. 2007; 31(3):417-426.

31. Vidal AM, Costa MAP de C, Souza A da S, Almeida WAB de, Souza FVD. In vitro regeneration and morphogenesis of somatic embryos of cassava. Rev Ciência Agron. 2014; 45(3):558-565.

32. Watt MP, Blakeway F, Mokoted MEO, Jain SM. Somatic embryogenesis in Eucalyptus grandis e E. dunnii. In: Jain SM, Gupta PK, Newton RJ. (Ed.). Somatic embryogenesis in woody plants, Dordrecht: Kluwer Academic Publishers; 1999. p.63-78.

33. Zimmermann MJ. Embriogênese somática: definição, usos e limitações. In: BRASILEIRO ACM (Ed.). Cultivo in vitro de plantas. Brasília: EMBRAPA Informação Tecnológica; 2010. p. 68-101. 